\title{
AN ANALYSIS OF THE DIRECTORS' DUTY TO ACT IN THE BEST INTERESTS OF THE COMPANY, THROUGH THE LENS OF THE BUSINESS JUDGMENT RULE
}

\author{
Jan Louis van Tonder
}

LLB LLM

Lecturer: Mercantile Law, Nelson Mandela

Metropolitan University, Port Elizabeth

Attorney and Conveyancer of the High Court of South Africa

\section{SUMMARY}

Directors are required to exercise their powers and perform their functions in good faith and for a proper purpose with the overarching promotional purpose being the best interests of the company. This is a fundamental duty which qualifies the exercise of any of the powers which the directors in fact have. The business-judgment rule provides the circumstances in which the duty to act in the best interests of the company (and the duty of care, skill and diligence) will be satisfied by a director. The main purpose of this article is to examine the meaning, nature and extent of the director's duty to act in the best interests of the company through the lens of the business-judgment rule. The duty to act in the best interests of the company will be considered in two different contexts, firstly as a phrase with the emphasis on the meaning of the word "interests" and "company"; secondly, as a "standard of directors' conduct" which will focus on the duty's link with the rationality criterion. In order to achieve the purpose of the article and due to the fact that the Companies Act 71 of 2008 partially codifies the fiduciary duties, the statutory interpretation of the standards of directors' conduct provision will also be considered. This will enable the research to properly interpret and analyse the relevant provisions in light of the common-law principles. Lastly, the research will identify categories of conduct that may not constitute good faith, thereby indicating that the rationality criterion will not be satisfied.

\section{INTRODUCTION}

Directors are required to exercise their powers and perform their functions in good faith and for a proper purpose ${ }^{1}$ with the overarching promotional

S 76(3)(a). 
purpose being the best interests of the company. ${ }^{2}$ This is a fundamental duty which qualifies the exercise of any of the powers which the directors in fact have. ${ }^{3}$ Previously South African company law relating to directors' duties was regulated by the common law ${ }^{4}$ and case law. ${ }^{5}$ These duties were derived from $18^{\text {th }}$ and $19^{\text {th }}$ century English company law which was judicially created and developed through continuous interpretation and application in case law. ${ }^{6}$ More than a decade ago in May 2004 the Department of Trade and Industry released a policy document entitled South African Company Law for the $21^{\text {st }}$ Century Guidelines for Corporate Law Reform. ${ }^{7}$ The document acknowledged that South Africa had no extensive statutory dispensation that covered the duties of directors and their possible

2 S 76(3)(b); See also Visser Sitrus (Pty) Ltd v Goede Hoop Sitrus (Pty) Ltd 2014 (5) SA 179 (WCC) par 80.

3 Minister of Water Affairs and Forestry v Stilfontein Gold Mining Co Ltd [2006] JOL 17516 (W) 31; Visser Sitrus (Pty) Ltd v Goede Hoop Sitrus (Pty) Ltd supra par 80; and see, for instance, s 38.

4 Delport (ed), Vorster, Burdette, Esser and Lombard Henochsberg on the Companies Act 71 of 2008 Vol 1 1ed (2011) 288 Preface (hereinafter referred to as "Henochsberg" in the text to avoid confusion with the editor's other publications).

5 Delport et al Henochsberg on the Companies Act 71 of 2008 288; Davis, Cassim and Geach Companies and Other Business Structures in South Africa: Commercial Law 2ed (2012) 110-111; Cilliers, Benade, Henning, Du Plessis, Delport, De Koker and Pretorius Corporate Law 3ed (2000) 139; Pretorius, Delport, Havenga and Vermaas Hahlo's South African Company Law Through the Cases 6ed (1999) 278; Cassim FHI, Cassim MF, Cassim R, Jooste, Shev and Yeats Contemporary Company Law 2ed (2012) 507; Cassim FHI, Cassim MF, Cassim R, Jooste, Shev and Yeats The Law of Business Structures (2012) 284; Stein and Everingham The New Companies Act Unlocked (2011) 18; Blackman, Jooste, Everingham, Yeats, Cassim and De La Harpe Commentary on the Companies Act Vol 2 (2002) (Loose leaf) (Revision service 8, 2011) 8-29; Williams "Companies" in Joubert and Faris (eds) The Law of South Africa Vol 4(2) (First Reissue "Duties of Directors and Officers"); The fiduciary duty of directors originates from Roman Dutch law while the common-law duty of care originates from English law - Jones "Directors' Duties: Negligence and the Business Judgment Rule" 200719 SA Merc LJ 326 327; Bouwman "An Appraisal of the Modification of the Director's Duty of Care and Skill" 200921 SA Merc LJ 509 510; Bekink "An Historical Overview of the Director's Duty of Care and Skill: From the Nineteenth Century to the Companies Bill of 2007" 200820 SA Merc LJ 95 97; and Williams in Joubert and Faris (eds) The Law of South Africa Vol 4(2) (First Reissue) par 116 fn 2 - indicating that "our courts have for most part relied on English decisions when developing our law of fiduciary duties, our fiduciary doctrine is of Roman Dutch origin".

6 Cassim et al Contemporary Company Law 507; Cassim et al The Law of Business Structures 284; DTI South African Company Law for the $21^{\text {st }}$ Century Guidelines for Corporate Law Reform 2004 12; Pretorius et al Hahlo's South African Company Law Through the Cases 1-3; Cilliers et al Corporate Law 23-28; and company law has existed in South Africa since 1861. It started with the Joint Stock Companies Limited Liabilities Act 23 of 1861 of the Cape Colony, which, along with other provincial company legislation, was the equivalent of English legislation. In 1926 South Africa's first national company law was introduced with the Union Companies Act. This Act was amended from time to time along the lines of the latest English legislation. The 1926 Act was replaced in 1973 with the 1973 Act, which, despite efforts to innovate and develop a direction more appropriate for South Africa, remained based on English law; See Cilliers et al Corporate Law 23-28; and DTI South African Company Law for the $21^{\text {st }}$ Century Guidelines for Corporate Law Reform 200412.

7 Published in GG 26493, GN 1183 of 2004 dated 2004-06-23, hereinafter "the policy document". 
accountability in the event of violations of those duties. ${ }^{8}$ The document recognised the need to bring South African company law in line with international trends and to reflect and accommodate the changing environment for businesses locally and internationally, whilst maintaining, encouraging and promoting compliance with the Bill of Rights as provided for in the Constitution.

The outcome of the reform process resulted in the proclamation of the Companies Act 71 of $2008^{10}$ which partially codifies $^{11}$ the duties of directors $^{12}$ and introduces the business judgment rule ${ }^{13}$ in the standards of the directors' conduct provision. ${ }^{14}$ The partial codification's intention is not to

8 Davis et al Companies and Other Business Structures in South Africa: Commercial Law 2ed 111; Davis, Geach, Mongalo, Butler, Loubser, Coetzee and Burdette Companies and Other Business Structures in South Africa: Commercial Law 3ed (2013) 116; and DTI South African Company Law for the 21 ${ }^{\text {st }}$ Century Guidelines for Corporate Law Reform 200417.

9 DTI South African Company Law for the $21^{\text {st }}$ Century Guidelines for Corporate Law Reform 2004 3;and s 7(a) of the 2008 Act. The Constitution of the Republic of South Africa, 1996 (the Constitution)

10 Hereinafter "the Act". The 2008 Act was signed into law by the State President on 8 April 2009 and was gazetted on 9 April 2009 in GG 32121 GN 421 as the Companies Act 71 of 2008. The Act was proclaimed into operation by GG 34239 R32 on 2011-05-01.

11 Delport et al Henochsberg on the Companies Act 71 of 2008 288; Cassim et al Contemporary Company Law 507; Davis et al Companies and Other Business Structures in South Africa: Commercial Law 2ed 110; Delport The New Companies Act Manual (2011) 90 , indicating that "[t]he statutory duties are not an exclusive or even proper codification of the common law duties"; Cassim et al The Law of Business Structures 285; Stein and Everingham The New Companies Act Unlocked 244; Bouwman 200921 SA Merc LJ 512; Esser and Du Plessis "The Stakeholder Debate and Director's Fiduciary Duties" 200719 SA Merc LJ 346 347; and s 76(2) read with s 77(2)(a), but does not exclude the common law, therefore the common-law duties that are not expressly amended by this section or those that are not in conflict with the provision will still apply, for example, duty not to exceed their powers; duty to exercise an unfettered and independent discretion - duty not to misappropriate corporate opportunities; duty to account for secret profits; duty not to improperly compete with the company; and a duty not to misuse confidential information. See s 76, 77(2) and 158(a).

13 S 76(4).

14 S 76 provides that:

"(1) In this section, 'director' includes an alternate director, and - (a) a prescribed officer; or (b) a person who is a member of a committee of a board of a company, or of the audit committee of a company, irrespective of whether or not the person is also a member of the company's board. (2) A director of a company must - (a) not use the position of director, or any information obtained while acting in the capacity of a director - (i) to gain an advantage for the director, or for another person other than the company or a wholly-owned subsidiary of the company; or (ii) to knowingly cause harm to the company or a subsidiary of the company; and (b) communicate to the board at the earliest practicable opportunity any information that comes to the director's attention, unless the director - (i) reasonably believes that the information is - (aa) immaterial to the company; or (bb) generally available to the public, or known to the other directors; or (ii) is bound not to disclose that information by a legal or ethical obligation of confidentiality. (3) Subject to subsections (4) and (5), a director of a company, when acting in that capacity, must exercise the powers and perform the functions of director (a) in good faith and for a proper purpose; (b) in the best interests of the company; and (c) with the degree of care, skill and diligence that may reasonably be expected of a person - (i) carrying out the same functions in relation to the company as those carried out by that director; and (ii) having the general knowledge, skill and experience of that director. (4) In respect of any particular matter arising in the exercise of the powers or the performance of the functions of director, a particular director of a company - (a) will have satisfied the obligations of subsection (3)(b) and (c) if - (i) the director has taken 
unreasonably jettison the common law. ${ }^{15}$ It is acknowledged that the benefits of a provision of this nature will need to be evaluated against the constraints it may place on the development of the common law. ${ }^{16}$ The Act does not expressly preserve or incorporate by reference the common-law principles with regard to the directors' duties but it also does not exclude the commonlaw principles in this regard. ${ }^{17}$ The principles of the common law relating to a breach of the directors' duties are preserved by the Act. ${ }^{18}$ Accordingly the common-law principles relating to the directors' duties are still relevant to determine the content of the duties to the extent that they are not in conflict with the provision.

The board is responsible for directing the management of a company, for monitoring its senior officers, and for making business decisions. ${ }^{20}$ In order to enable the board to carry out this responsibility it is conferred with the statutory authority to exercise all the powers and perform any of the functions of the company. ${ }^{21}$ It applies to all decisions directors make, or should, where they exercise their powers for the benefit of the company. ${ }^{22}$ The fiduciary duties require directors, when acting in that capacity, to exercise their powers and perform their functions in good faith and for a proper purpose in the best interests of the company. ${ }^{23}$ The duty of care, skill

reasonably diligent steps to become informed about the matter; (ii) either - (aa) the director had no material personal financial interest in the subject matter of the decision, and had no reasonable basis to know that any related person had a personal financial interest in the matter; or $(\mathrm{bb})$ the director complied with the requirements of section 75 with respect to any interest contemplated in subparagraph (aa); and (iii) the director made a decision, or supported the decision of a committee or the board, with regard to that matter, and the director had a rational basis for believing, and did believe, that the decision was in the best interests of the company; and (b) is entitled to rely on - (i) the performance by any of the persons - (aa) referred to in subsection (5); or (bb) to whom the board may reasonably have delegated, formally or informally by course of conduct, the authority or duty to perform one or more of the board's functions that are delegable under applicable law; and (ii) any information, opinions, recommendations, reports or statements, including financial statements and other financial data, prepared or presented by any of the persons specified in subsection (5). (5) To the extent contemplated in subsection (4)(b), a director is entitled to rely on - (a) one or more employees of the company whom the director reasonably believes to be reliable and competent in the functions performed or the information, opinions, reports or statements provided; (b) legal counsel, accountants, or other professional persons retained by the company, the board or a committee as to matters involving skills or expertise that the director reasonably believes are matters - (i) within the particular person's professional or expert competence; or (ii) as to which the particular person merits confidence; or (c) a committee of the board of which the director is not a member, unless the director has reason to believe that the actions of the committee do not merit confidence."

15 DTI South African Company Law for the $21^{\text {st }}$ Century Guidelines for Corporate Law Reform 20047.

16 lbid.

17 S 77(2); and see also Williams "Companies" in Joubert and Faris (eds) The Law of South Africa Vol 4(1) par 238 fn 5.

18 See s 77(2)(a) and (b).

19 Delport et al Henochsberg on the Companies Act 71 of 2008288.

20 See s 66(1) read with s 76

21 S 66(1).

22 Bekink 200820 SA Merc LJ 95; and Havenga "The Business Judgment Rule - Should we Follow the Australian Example?" 200012 SA Merc LJ 25.

$23 \quad S 76(2)$ and $(3)(a)(b)$ 
and diligence regulates the performance of these duties. ${ }^{24}$ The business judgment rule ${ }^{25}$ provides the circumstances in which the duty to act in the best interests of the company and the duty of care, skill and diligence will be satisfied by a director. ${ }^{26}$ The justifications for the deference aspect of the business judgment rule are multifaceted but usually begin with the fact that directors are conferred with a statutory authority to manage the business and affairs of the company on whose board they serve. ${ }^{27}$ In turn, it is recognised that the exercise of this statutory power carries with it certain fundamental fiduciary obligations to the company. ${ }^{28}$ The imposition of fiduciary duties on directors thus provides an underlying premise for the separation of legal control from ownership. ${ }^{29}$

The main purpose of this article is to examine the meaning, nature and extent of the directors' duty to act in the best interests of the company through the lens of the business judgment rule. The article will examine whether the duty introduced in the standards of conduct provision is aligned with the common-law principles relating to that duty. It will consider whether the standards of conduct provision amends the common-law principles, adds anything new or narrows the duty in its statutory format.

According to the specific structure of the relevant provisions ${ }^{30}$ and its technical layout the duty to act in good faith and for a proper purpose ${ }^{31}$ stands individually, albeit in the same subsection, from the duty to act in the best interests of the company. ${ }^{32}$ Owing to the specific structure ${ }^{33}$ of subsection (3)(a) and subsection (3)(b), read with subsection (4)(a), the article will approach the duties in a similar manner. The duty to act in the best interests of the company will be considered in two different contexts, firstly as a phrase with the emphasis on the meaning of the words "interests" and "company", secondly, as a "standard of directors' conduct" which will focus on the duty's link with the rationality criterion. In order to achieve the purpose of the article and due to the fact that the 2008 Act partially codifies the fiduciary duties, the statutory interpretation of the standards of directors conduct provision will be considered first. This will enable the research to properly interpret and analyse the relevant provisions in light of the commonlaw principles.

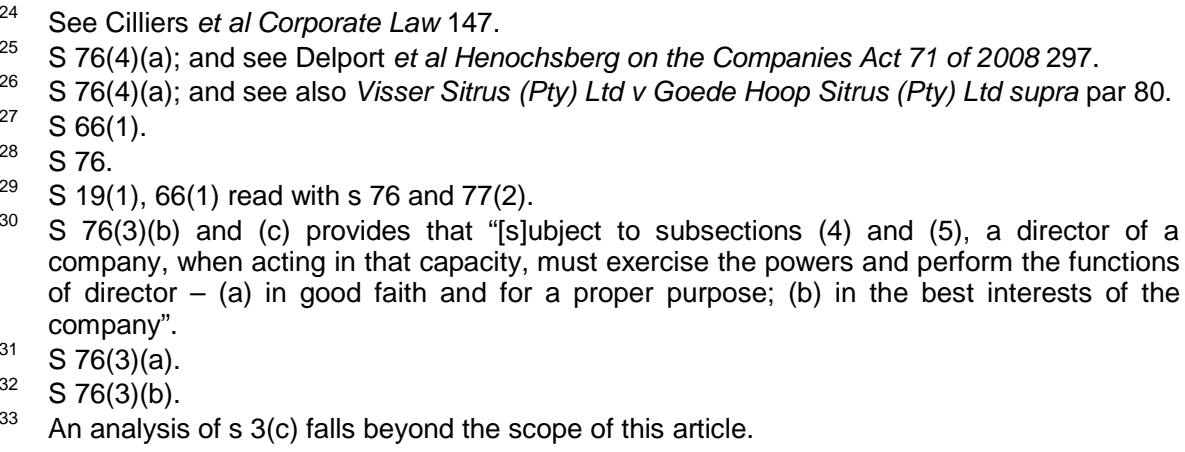
company, when acting in that capacity, must exercise the powers and perform the functions of director - (a) in good faith and for a proper purpose; (b) in the best interests of the company".

${ }^{31} \mathrm{~S} 76(3)(a)$

S 76(3)(b).

An analysis of s 3(c) falls beyond the scope of this article. 


\section{STATUTORY INTERPRETATION OF THE STANDARDS OF DIRECTORS' CONDUCT PROVISION}

The fiduciary duties of directors in South Africa are partially codified in the standards of directors' conduct provision. ${ }^{34}$ If the standards of directors' conduct provision was intended to be a complete codification of directors' duties, the Act must either explicitly say that it is the intention of the legislature to supersede the common law, or the inference from the Act must be such that one can come to no other conclusion than that the legislature did have such an intention. ${ }^{35}$ It is not the intention of the Act to replace the common-law duties of directors, to the extent that they are not in conflict with the standards of directors conduct provision. ${ }^{36}$ This was made clear by the policy document, ${ }^{37}$ and is supported by the Act. ${ }^{38}$ The Act also authorises and encourages the development of the common law. ${ }^{39}$ This will effectively provide the courts with the ability to develop the duties further in a South African context. ${ }^{40}$ An understanding of the common-law principles relating to directors' duties is still necessary to determine the interaction between the common-law duties and the standards of directors' conduct provision,

${ }^{34}$ S 76 read with s 77(2), but does not exclude the common law, therefore the common law duties that are not expressly amended by this section or those that are not in conflict with the provision will still apply, for example, duty not to exceed their powers; duty to exercise an unfettered and independent discretion; duty not to misappropriate corporate opportunities; duty to account for secret profits; duty not to improperly compete with the company; and a duty not to misuse confidential information.

35 Casserley v Stubbs 1916 TPD 310 312; Rand Bank Bpk v Regering van die Republiek van Suid-Afrika 19744 All SA 552 (T); 1974 (4) SA 764 (T) 767D-F; S v Khumbisa 1984 (2) SA 670 (N) 680; see also the earlier case of Johanessburg Municipality $v$ Cohen's Trustees: 823, where Solomon $\mathrm{J}$ quoted the rule laid down in a English case by Byles $\mathrm{J}$ in Reg. $v$ Morris (1 CCR 95): "It is a sound rule to construe a statute in conformity with the common law rather than against it, except where and so far as the statute is plainly intended to alter the course of the common law"; and, eg, of express modifications see s 170(3) of the UK Companies Act 2006 and s 165(1) of the 2008 Act which provides that, in respect of derivative actions, any right at common law of a person other than a company to bring or prosecute any legal proceedings on behalf of that company is abolished, and the rights in this section are in substitution for any such abolished right.

36 Delport The New Companies Act Manual 90; Delport et al Henochsberg on the Companies Act 71 of 2008 288; Davis et al Companies and Other Business Structures in South Africa: Commercial Law 2ed 111: Cassim et al Contemporary Company Law 509; Cassim et al The Law of Business Structures 284-285; Stein and Everingham The New Companies Act Unlocked 244; and Williams in Joubert and Faris (eds) The Law of South Africa Vol 4(1) par 238 fn. 5.

37 DTI South African Company Law for the $21^{\text {st }}$ Century Guidelines for Corporate Law Reform 20047.

38 See s 5(2), 7, 77(2) and 158(a); and see Kensal Rise Investments (Pty) Limited $v$ Marchant (1523/2013) [2014] ZAKZDHC 47 (30 October 2014) par 12, where it was submitted that the 2008 Act as a whole is not a codification of the law relating to the fiduciary relationship between directors and their companies, with the result that conduct not forbidden by the 2008 Act is now sanctioned.

39 See s 5(2), 76, 77(2) and 158(a).

40 See Amdocs SA Joint Enterprise (Pty) Ltd v Kwezi Technologies (Pty) Ltd 2014 (5) SA 532 (GJ) par 8, where the court submitted that even if the statutory provisions are identical, the different common-law principles as informed by the Constitution, may lead a court to reach a different conclusion as to the meaning. 
especially to determine the content of the duties. ${ }^{41}$ The relationship between the statutory provision and the common law must be clear. ${ }^{42}$

The Act further provides for a general interpretation provision ${ }^{43}$ and $a$ provision setting out the purposes ${ }^{44}$ the Act intends to achieve. ${ }^{45}$ Interpretation and purpose clauses have frequently been included after the implementation of the Constitution. ${ }^{46}$ They give an immediate overall picture of what the Act wants to achieve. ${ }^{47}$ They help to explain the purposes of the Act and how it should be interpreted. ${ }^{48}$ They constitute internal language aids and will assist with the proper interpretation of the Act. ${ }^{49}$ Courts will be required to analyse the Act together with the internal (and external) aids of interpretation. ${ }^{50}$

Courts must interpret the language of the Act to give effect to the purposes the Act intends to achieve. ${ }^{5}$ The Act lists several purposes. ${ }^{52}$ The

41 Delport The New Companies Act Manual 90; Delport et al Henochsberg on the Companies Act 71 of 2008 288; Davis et al Companies and Other Business Structures in South Africa: Commercial Law 2ed 111; Cassim et al Contemporary Company Law 509; Cassim et al The Law of Business Structures 284-285; Stein and Everingham The New Companies Act Unlocked 244; and Williams in Joubert and Faris (eds) The Law of South Africa Vol 4(1) par 238 fn 5.

42

Esser Recognition of Various Stakeholder Interests in Company Management (Doctoral thesis, University of South Africa (UNISA) (2008)) 298; and Delport et al Henochsberg on the Companies Act 71 of 2008289.

$43 \mathrm{~S} 5$.

44 S 7.

45 See Jooste The Comparative Guide to the Old and New Companies Acts (2011) 804. The author does not list a comparable provision of the 1973 Act to $s$ or 7 of the 2008 Act.

46 Botha Statutory Interpretation: An Introduction for Students 5ed (2013) 38.

47 lbid.

48 Ibid.

49 Botha Statutory Interpretation: An Introduction for Students 115.

Botha Statutory Interpretation: An Introduction for Students 120.

See s 5(1), s 6(1) and 7.

S 7 provides that:

"The purposes of this Act are to - (a) promote compliance with the Bill of Rights as provided for in the Constitution, in the application of company law; (b) promote the development of the South African economy by - (i) encouraging entrepreneurship and enterprise efficiency; (ii) creating flexibility and simplicity in the formation and maintenance of companies; and (iii) encouraging transparency and high standards of corporate governance as appropriate, given the significant role of enterprises within the social and economic life of the nation; (c) promote innovation and investment in the South African markets; (d) reaffirm the concept of the company as a means of achieving economic and social benefits; (e) continue to provide for the creation and use of companies, in a manner that enhances the economic welfare of South Africa as a partner within the global economy; (f) promote the development of companies within all sectors of the economy, and encourage active participation in economic organisation, management and productivity; (g) create optimum conditions for the aggregation of capital for productive purposes, and for the investment of that capital in enterprises and the spreading of economic risk; (h) provide for the formation, operation and accountability of non-profit companies in a manner designed to promote, support and enhance the capacity of such companies to perform their functions; (i) balance the rights and obligations of shareholders and directors within companies; (j) encourage the efficient and responsible management of companies; (k) provide for the efficient rescue and recovery of financially distressed companies, in a manner that balances the rights and interests of all relevant stakeholders; and (I) provide a predictable and effective environment for the efficient regulation of companies." 
purposes of the Act that may be promoted through the application of, and are relevant to, the standards of directors' conduct provision includes:

(i) compliance with the Bill of Rights as provided for in the Constitution; ${ }^{53}$

(ii) the encouragement of higher standards of corporate governance $;^{54}$

(iii) to reaffirm the concept of the company as a means of achieving economic and social benefits; ${ }^{55}$

(iv) to balance the rights and obligations of shareholders and directors within companies; ${ }^{56}$

(v) to encourage the efficient and responsible management of companies; ${ }^{57}$ and

(vi) to provide a predictable and effective environment for the efficient regulation of companies. ${ }^{58}$

The Act also provides remedies to ensure that the promotion of these purposes may be achieved. ${ }^{59}$ When a matter is required to be determined in terms of the directors' standard of conduct provision a court must develop the common law as necessary to improve the realisation and enjoyment of rights established by the Act. ${ }^{60}$ It must promote the spirit, purpose and objects of the Act, ${ }^{61}$ and if the directors' standard of conduct provision, read in its context, can be reasonably construed to have more than one meaning, the court must prefer the meaning that best promotes the spirit and purpose of the Act and will best improve the realisation and enjoyment of rights. ${ }^{62}$ The aim of the partial codification is not to revoke the common law but to ensure that the partial codification is appropriate to the legal, economic and social context of South Africa as a constitutional democracy and open economy. ${ }^{63}$

S 7(a). The Constitution of the Republic of South Africa, 1996 (the Constitution).

$S 7$ (b)(iii).

S $7(d)$.

S 7(i).

$S 7(j)$.

$S 7(1)$.

S 158.

S 158(a).

S 158(b)(i). See the DTI South African Company Law for the $21^{\text {st }}$ Century Guidelines for Corporate Law Reform 2004; and the DTI Notice of intention to introduce a Bill into Parliament, GG 29630 GN 166 of 2007-02-12 for a background the on the spirit and objectives of the Act.

62 S 158(b)(ii).

63 The Department of Trade and Industry, Companies Bill 2007: Notice of Intention to Introduce a Bill into Parliament in GG 29630, GN 166 of 2007; and DTI South African Company Law for the $21^{\text {st }}$ Century Guidelines for Corporate Law Reform 20047. 


\section{THE BUSINESS JUDGMENT RULE}

\section{Introduction}

A registered company is a juristic person ${ }^{64}$ that exists separately from its management and shareholders. ${ }^{65} \mathrm{~A}$ company cannot act on its own. ${ }^{66}$ It conducts its affairs through representatives. ${ }^{67}$ It is now a matter of statutory law that the company's business and affairs must be managed by or under the direction of its board. ${ }^{68}$ Accordingly the board has the authority to exercise all of the powers and perform any of the functions of the company. ${ }^{69}$ The importance of the statutory managerial authority is twofold, namely ${ }^{70}$ the statutory power to manage the company is now original instead of delegated, ${ }^{71}$ and the ultimate power to manage the company is now with the board of directors. ${ }^{72}$ The company will accordingly be subject to a lesser degree of shareholders' control, ${ }^{73}$ and directors now have a positive duty to manage the company.

Accordingly the standards of directors' conduct provision provides that, directors'-subject to the business judgment rule $^{75}$ and the standard of conduct that relates to the board's ability to manage the business and affairs of the company under its direction, ${ }^{76}$ a director of a company, when acting in that capacity, must exercise the powers and perform the functions of director, $^{77}$ in good faith and for a proper purpose, ${ }^{78}$ in the best interests of the company ${ }^{79}$ and with the degree of care, skill and diligence that may reasonably be expected of a person ${ }^{80}$ carrying out the same functions in

64 See s 19(1).

65 See s 19(1)(a) and (b); Kennedy-Good and Coetzee "The Business Judgment Rule (Part 1)" 200627 Obiter 6263

66 Kennedy-Good and Coetzee 200627 Obiter 63; and Cassim et al Contemporary Company Law 187.

67 Kennedy-Good and Coetzee 200627 Obiter 63; and eg, directors and officers, Cassim et al Contemporary Company Law 187.

68 S 66(1).

69 Except to the extent that this Act or the company's Memorandum of Incorporation provides otherwise - s 66(1).

70 Delport et al Henochsberg on the Companies Act 71 of 2008 248; and Cassim et al Contemporary Company Law 507.

71 Delport et al Henochsberg on the Companies Act 71 of 2008248.

72 Delport et al Henochsberg on the Companies Act 71 of 2008 248; and Cassim et al Contemporary Company Law 507.

73 Havenga "Directors' Exploitation of Corporate Opportunities and the Companies Act 71 of 2008" 2013 TSAR 257 262; and Cassim et al Contemporary Company Law 507.

74 Delport et al Henochsberg on the Companies Act 71 of 2008 248; Delport The New Companies Act Manual 90 fn 68; Havenga 2013 TSAR 262; and Cassim et al Contemporary Company Law 507.

75 S 76(4)(a)-(b).

76 S 76(5).

77 S 76(3).

78 S 76(3)(a).

79 S 76(3)(b).

$80 \mathrm{~S} 76(3)(\mathrm{c})$ 
relation to the company as those carried out by that director, ${ }^{81}$ and having the general knowledge, skill and experience of that director. ${ }^{82}$

Section 76(4) introduces the business judgment rule. ${ }^{83}$ In terms of the provision in respect of any particular matter arising in the exercise of the powers or the performance of the functions of director, a particular director of a company ${ }^{84}$ will have satisfied his duty to exercise his powers, or performed his functions in the best interests of the company and with reasonable care, skill and diligence if: ${ }^{85}$

(i) the director has taken reasonably diligent steps to become informed about the matter; ${ }^{86}$

(ii) either $-{ }^{87}$

(aa) the director had no material personal financial interest in the subject matter of the decision, and had no reasonable basis to know that any related person had a personal financial interest in the matter; ${ }^{88}$ or

(bb) the director complied with the requirements of section 75 with respect to any interest contemplated in subparagraph (aa) $;{ }^{89}$ and

(iii) the director made a decision, or supported the decision of a committee or the board, with regard to that matter, and the director had a rational basis for believing, and did believe, that the decision was in the best interests of the company. ${ }^{90}$

The business judgment rule ${ }^{91}$ thus provides the circumstances in which the duties imposed by subsection (3)(b) and (c) ${ }^{92}$ of the standards of directors' conduct provision will be satisfied by a director. ${ }^{93}$

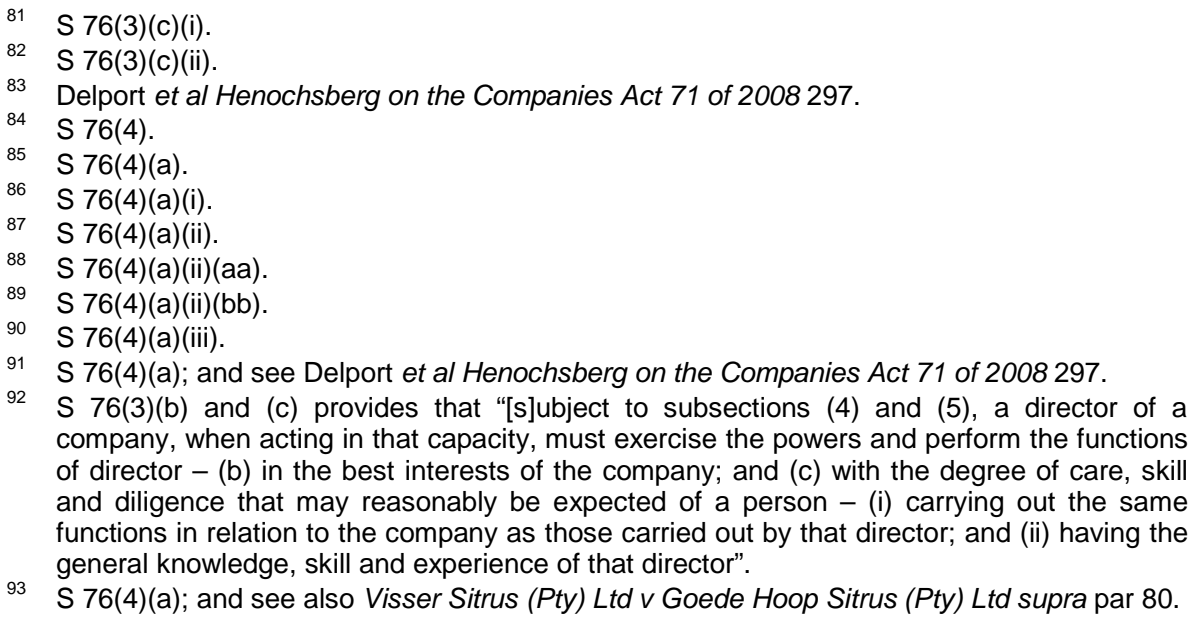
of director - (b) in the best interests of the company; and (c) with the degree of care, skill and diligence that may reasonably be expected of a person - (i) carrying out the same functions in relation to the company as those carried out by that director; and (ii) having the general knowledge, skill and experience of that director".

93 S 76(4)(a); and see also Visser Sitrus (Pty) Ltd v Goede Hoop Sitrus (Pty) Ltd supra par 80. 


\section{The duty to act in the best "interests" of the "company"}

On its formation a company is a legal entity that exists separately from its management and shareholders. ${ }^{94}$ As a general rule directors owe a fiduciary duty to the company as a whole and as a separate legal entity. ${ }^{95}$ Directors are required to exercise their powers and perform their functions in the best interests of the company. ${ }^{96}$ The "best interests of the company" is an indefinite phrase and possibly has different meanings in different contexts. ${ }^{97}$

It is clear that the precise wording of "company" in section 76(3)(b) and in section 77(2)(a) and (b) that "[a] director of company may be held liable ... for any loss, damages or costs sustained by the company as a consequence of any breach", removes any doubt that the duties are owed to the company. The problematic area is whose "interests" are referred to with the word "company". ${ }^{98}$ The general rule is that "the interests of the company as a whole" are the interests of the shareholders qua shareholders, as a general body and the company as a separate legal entity. ${ }^{99}$ This approach relates to the shareholders collectively, all the shareholders both present and future and the company as a separate legal entity. ${ }^{100}$ This indicates their interests in the prosperity of the company as a business concern. ${ }^{101}$ Directors do not owe fiduciary duties to shareholders as such. ${ }^{102}$ They are required to act in good faith in the interests of the company seen as the interests of the shareholders collectively. ${ }^{103}$ Shareholders should be treated equally. ${ }^{104}$

Sealy ${ }^{105}$ submits that the phrase has a notoriously elusive meaning and "[m]odern commentators strive to make it mean all things to all men by adding gloss after gloss - shareholders present and future, employees, creditors - so that what emerges is an ill-focused conglomerate". According to Sealy ${ }^{106}$ the better view is that it can mean different things in different contexts. One of the purposes of the Act is to reaffirm the concept of the company as a means of achieving economic and social benefits. ${ }^{107}$ It is

94 Cilliers et al Corporate Law 139.

95 Blackman et al Commentary on the Companies Act 8-51; and Cilliers et al Corporate Law 139.

96 S 76(3)(b).

97 Blackman et al Commentary on the Companies Act 8-67; Sealy 'Bona Fides' and 'Proper Purposes' in Corporate Decisions" 1989 Monash University LR 265 269-270; and see also Mills v Mills [1938] HCA 4; (1938) 60 CLR 150 188-189.

$98 \mathrm{~S} 1$ defines the word "company" as "a juristic person incorporated in terms of the Act". This definition is of little relevance in the context of this discussion. Cassim et al Contemporary Company Law 515 fn 39.

99 Blackman et al Commentary on the Companies Act 8-67; and Delport et al Henochsberg on the Companies Act 71 of 2008296.

100 Esser Recognition of Various Stakeholder Interests in Company Management 211.

101 Blackman et al Commentary on the Companies Act 8-69.

102 Esser Recognition of Various Stakeholder Interests in Company Management 211.

$103 \mathrm{Ibid}$.

104 Ibid.

105 Sealy 1989 Monash University LR 269-270.

106 Sealy 1989 Monash University LR270.

107 S 7(d). 
construed to mean that this section should be interpreted that directors must pay attention to the interests of stakeholders as well, but does not provide stakeholders with direct rights. ${ }^{108}$ This approach involves the "enlightened shareholder value" approach. ${ }^{109}$ With the enlightened shareholder approach the legitimate interests and expectations of other stakeholders are considered so far as it would promote long-term profit maximisation. ${ }^{110}$ Pretorius $^{111}$ submits that "[i]rrespective of what the legal rules are, good management will attempt to balance the interests of shareholders, employees, creditors, consumers[, the environment ${ }^{112}$ and society in general, having regard to the nature and size of the company and the interests most affected by any particular transaction or decision".

\section{The duty to act in the best interests of the company as a standard of directors' conduct and its link with the rationality criterion}

According to Pretorius ${ }^{113}$ "[t]he paramount duty of directors, individually and collectively, is to exercise their powers bona fide in the best interests of the company". The common-law principle of "bona fide" appears to have been renamed as "good faith". ${ }^{114}$ Directors are required to exercise their powers

108 Van der Merwe, Appleton, Delport, Furney, Mahony and Koen South African Corporate Business Administration (1995) (Revision service 17, 2011) 15-2; Delport et al Henochsberg on the Companies Act 71 of 2008 46(4); and this was also the view expressed in the South African Company Law for the $21^{\text {st }}$ Century Guidelines for Corporate Law Reform 2004.

109 Delport et al Henochsberg on the Companies Act 71 of 2008 46(4).

110 lbid.

111 Pretorius et al Hahlo's South African Company Law Through the Cases 294.

112 In Company Secretary of Arcelormittal South Africa v Vaal Environmental Justice Alliance [2015] 1 All SA 261 (SCA) 288, Navsa ADP said that:

"I accept that this relates principally to the state. However, the same must, in principle, apply to corporate decisions and activities that impact on the environment and thus implicate the public interest, particularly when their activities require regulatory approval" (288).

"[i]t is clear, therefore, in accordance with international trends, and constitutional values and norms, that our Legislature has recognised, in the field of environmental protection, inter alia, the importance of consultation and interaction with the public. After all, environmental degradation affects us all. One might rightly speak of collaborative corporate governance in relation to the environment" (281).

113 Pretorius et al Hahlo's South African Company Law Through the Cases 279.

114 S 76(3)(a). Sealy 198915 Monash University LR 266, notes that these two elements of the duty are now set out under separate headings, namely, a duty to act in good faith and a duty to use powers for a proper purpose in consequence of the line of cases beginning with Hogg v Cramphorn Ltd [1966] 3 All ER 420, in which it appeared that a distinction was being made between these two requirements. Sealy 1989 Monash University LR 269 points out that the expression "bona fide" is not free from ambiguity. It has two dictionary meanings: "in good faith", and "genuine". The former, a subjective application, is more naturally used in relation to human beings, in the sense of "honestly, with the best of intentions". In contrast, and more objectively, we may describe an act, activity or state of affairs as "bona fide", meaning "genuine": eg, we can speak of a shareholders' resolution as being a bona fide expression of corporate opinion when it has not been blurred by some irregularity such as the rigging of votes or the bribery, intimidation or improper bias of some of the members. Sealy 1989 Monash University LR 269 argues that most of the confusion would have been avoided if the time-honoured phrase, "bona fide in the interests of the company as a whole" had always been understood in the second of these senses. The 
and perform their functions in good faith for the benefit of what they believe is the best interests of the company. ${ }^{115}$ This is considered to be a fundamental duty ${ }^{116}$ which is now imposed by both the common law and the Act. $^{117}$

The aspect of good faith largely depends, though not exclusively, on honesty. ${ }^{118}$ Honesty is subjective and a breach of this duty consequently requires subjective awareness. ${ }^{119}$ Under the common law the courts have on several occasions indicated that they will not second-guess the decisions properly taken by directors as part of the powers conferred upon them. ${ }^{120}$ If directors exercise business judgment honestly and in good faith the courts will not substitute its opinion for that of the management or question the correctness of the management's decision on that particular issue. ${ }^{121}$ Under the common law this judicial policy ${ }^{122}$ primarily relates to cases decided under the "proper purpose" rule, but implicates decisions that are not made in the best interests of the company. ${ }^{123}$ The courts will not assume to act as a kind of supervisory board over decisions within the powers of management honestly arrived at. ${ }^{24}$ The issue concerns the directors' subjective state of mind. ${ }^{12}$

In Re Smith and Fawcett ${ }^{126}$ the court held that directors must exercise their powers "bona fide in what they consider - not what a court may consider - to be in the best interests of the company, and not for a collateral

current English view that regards "proper purposes" as a separate test probably developed because the words "bona fide" had wrongly become separated from the composite phrase, leading to a contention that a subjective honesty of purpose was all that needed to be shown in order to repel a challenge to the exercise of a discretion. This has never been the case, either in relation to powers generally or more specifically in the context of corporate powers.

115 S 76(3)(a) and (b); see Da Silva v CH Chemicals (Pty) Ltd [2009] 1 All SA 216 (SCA) 221; Blackman et al Commentary on the Companies Act 8-57; Williams in Joubert and Faris (eds) The Law of South Africa Vol 4(2) (First Reissue) par 121; and Cassim et al Contemporary Company Law 525.

116 The core or basis of the fiduciary duties is loyalty, good faith and honesty. Cassim et al Contemporary Company Law 509 and 514.

117 S 76(3)(a) and (b); and Cassim et al Contemporary Company Law 523.

118 Cassim et al Contemporary Company Law 524. A fiduciary duty may be breached without dishonesty and even though the director was honest. Mere incompetence of a director, by itself, is, however, not necessarily a breach of a fiduciary duty. Cassim et al Contemporary Company Law 514.

119 Cassim et al Contemporary Company Law 524

120 Du Plessis "Directors' Duty to Use their Powers for Proper or Permissible Purposes" 2004 16 SA Merc LJ 308312.

121 Howard Smith Ltd v Ampol Petroleum Ltd [1974] 1 All ER 11261131.

122 See Farrar "Directors' Duties of Care: Issues of Classification, Solvency and Business Judgment and the Dangers of Legal Transplants" 2011 Singapore Academy of LJ 745757.

123 Sealy 1989 Monash University LR 265; Fridman "An Analysis of the Proper Purpose Rule" 199810 Bond LR 164; Du Plessis 200416 SA Merc LJ 308; and Blackman et al Commentary on the Companies 8-57 and 8-64.

124 Howard Smith Ltd v Ampol Petroleum Ltd supra 1131; see also Hogg v Cramphorn supra 428; Harlowe's Nominees Pty Ltd v Woodside (Lakes Entrance) Oil Co NL [1968] HCA 37; (1968) 121 CLR 483 par 6; and Mills v Mills supra 163 and 169.

125 Greenhalgh v Arderne Cinemas [1950] 2 All ER 11201126.

126 [1942] 1 All ER 542. 
purpose". ${ }^{127}$ This aspect of the duty is subjective. ${ }^{128}$ Directors must assess honestly and in good faith that which they consider to be the best interests of the company. ${ }^{129}$ According to Sealy ${ }^{130}$ the subjective test confirms the view that business decisions are matters for business men and not subject to review by the courts. Sealy ${ }^{131}$ submits that the subjective test is a venerable test but there has always been a bottom line, an objective threshold of reasonableness below which good faith or bona fides will not in itself be sufficient for a valid and enforceable decision.

In Shuttleworth $v$ Cox Brothers \& Co (Maidenhead) Ltd ${ }^{132}$ the court held that, in the absence of any reasonable ground for deciding that a certain course of action is made for the benefit of the company, may be a ground for finding lack of good faith. ${ }^{133}$ The absence of a reasonable ground for believing that the director is acting in the interests of the company may be the basis for finding lack of good faith. ${ }^{134}$ The objective test formulated by Pennycuick $\mathrm{J}$, in Charterbridge Corporation Ltd $v$ Lloyds Bank Ltd ${ }^{135}$ is whether an intelligent and honest person, in the position of a director of the company concerned, could, in the whole of the existing circumstances, have reasonably believed that the transaction was for the benefit of the company.

The cumulative effect of the subjective test provided for in Re Smith and Fawcett, ${ }^{137}$ read with the objective test provided for in Shuttleworth $v$ Cox Brothers \& Co (Maidenhead) Ltd ${ }^{138}$ and Charterbridge Corporation Ltd $v$ Lloyds Bank Ltd $^{139}$ is in accordance with subsection (4)(a)(iii) which indicates that the standard of conduct imposed by subsection (3)(b), is not an objective one, in the sense of allowing a court, if a board decision is challenged, to determine what is objectively speaking in the best interests of

127 Re Smith and Fawcett supra 543.

128 Blackman et al Commentary on the Companies Act 8-64; and Cassim et al Contemporary Company Law 524.

129 Howard Smith Ltd v Ampol Petroleum Ltd supra 1131; see also Hogg v Cramphorn supra 428; Harlowe's Nominees Pty Ltd v Woodside (Lakes Entrance) Oil Co NL supra par 6; and Mills $v$ Mills supra 163 and 169.

130 Sealy 1989 Monash University LR 277.

131 Ibid.

132 [1927] 2 KB 9. See also Extrasure Travel Insurances Ltd v Scattergood [2003] 1 BCLC 598 (ChD) 619, where the court held that there must reasonable grounds for the belief of the directors that they were acting in the best interests of the company.

133 Shuttleworth $v$ Cox Brothers \& Co (Maidenhead) Ltd supra 23.

134 Cassim et al Contemporary Company Law 524.

135 [1969] 2 All ER 1185.

136 Charterbridge Corporation Ltd $v$ Lloyds Bank Ltd supra 1194; and see also in Teck Corporation v Miller (1972) 33 DLR (3d) 288 315-316 the court held that "[t]he directors must act in good faith. Then there must be reasonable grounds for their belief. If they say that they believe there will be substantial damage to the company's interests, then there must be reasonable grounds for that belief. If there are not, that will justify a finding that the directors were actuated by an improper purpose."

137 [1942] 1 All ER 542.

138 Supra. See also Extrasure Travel Insurances Ltd $v$ Scattergood supra 619, where the court held that there must reasonable grounds for the belief of the directors that they were acting in the best interests of the company.

139 Supra. 
the company. ${ }^{140}$ This indicates that, after having taken reasonably diligent steps to become informed about a matter, directors should subjectively have believed that their decision was in the best interests of their company and this belief must have had "a rational basis". ${ }^{141}$ The business judgment rule confirms this position by requiring the directors' bona fide or good faith assessment to have a rational underpinning. ${ }^{142}$

In terms of the business-judgment rule the rationality criterion provides for an objective assessment relating to what "a reasonable person in their position will hold" but may also include an assessment of what "no reasonable person in their position will hold". ${ }^{143}$ According to Rogers J, "the 'no reasonable director' test is merely an aid [used] in answering the ultimate factual question, which is whether the directors were acting in what they bona fide believed to be the best interests of the company". "14 "If the decision-making process is conducted in good faith, with no personal financial self-interest and with due care, the presupposition of a rational business purpose will be established. ${ }^{145}$ If the requirements of the businessjudgment rule are established, "rational belief" provides considerable protection to directors. ${ }^{146}$ In extreme circumstances where directors blindly believe something that "no other person in their position" will believe, a court will refuse the protection of the business judgment rule based on the fact that it was not a rational belief that their business judgment was in the best interests of the corporation.

According to the research the business judgment rule may find application in personal-liability cases as well as transactional justification matters which includes matters relating to an alteration of articles, ${ }^{148}$ adequacy of consideration of shares, reduction of capital, refusal to register transfers, ${ }^{149}$ schemes of arrangements and takeover cases.

In Hogg $v$ Cramphorn $L t d^{151}$ the directors of a company, in order to prevent a hostile takeover from succeeding, acting in what they believed was

140 Visser Sitrus (Pty) Ltd v Goede Hoop Sitrus (Pty) Ltd supra par 74.

141 See Re Smith \& Fawcett Ltd supra; and Visser Sitrus (Pty) Ltd v Goede Hoop Sitrus (Pty) Ltd supra par 74.

142 See s 76(4)(a)(iii); and Visser Sitrus (Pty) Ltd v Goede Hoop Sitrus (Pty) Ltd supra par 80.

143 Du Plessis, Hargovan and Bagaric Principles of Contemporary Corporate Governance (2011) 246.

144 Visser Sitrus (Pty) Ltd $v$ Goede Hoop Sitrus (Pty) Ltd supra par 74.

145 Visser Sitrus (Pty) Ltd v Goede Hoop Sitrus (Pty) Ltd supra par 74-76.

${ }_{146}$ Du Plessis et al Principles of Contemporary Corporate Governance 246.

147 Ibid.

148 Shuttleworth $v$ Cox Brothers \& Co. (Maidenhead) Ltd supra.

149 Re Smith and Fawcett supra; and Visser Sitrus (Pty) Ltd v Goede Hoop Sitrus (Pty) Ltd supra.

150 Howard Smith Ltd v Ampol Petroleum Ltd supra.

151 Supra. The board of directors allotted unissued preference shares to the trust. The preference shares that were granted, contrary to the company's constitution, carried special voting rights (10 votes per share). An interest free loan was extended to the trust to enable the trustees to pay for the shares. In the Canadian matter of Teck Corp Ltd v Millar supra Berger J, was of the opinion that this matter should not be followed. The court opined that directors were entitled to consider the consequences of a takeover and the reputation, experience and policies of anyone seeking to take over the company. If the directors then decide on reasonable grounds that a takeover would not be in the best interests of the 
in good faith and in the best interests of the company, set up a trust for the purposes of creating an employee share scheme for the benefit of the employees of the company. ${ }^{152}$ The directors expected the trustees, whom they thought were their allies, to cast their votes in support of the directors rather than the takeover bidder.

The court accepted that the transaction was not tainted by any selfinterest due to the directors' belief that they acted in good faith and in the best interests of the company. ${ }^{154}$ However, Buckley $\mathrm{J}$, held that this exercise of the directors' power to allot shares was for an improper purpose. ${ }^{155}$ The court held that an essential element of the scheme was to ensure that the directors and their supporters remain in control of the company. ${ }^{156}$ The manipulation of the voting position in the company was not a legitimate act by the directors. ${ }^{157}$ The court held that the issuing of shares is a fiduciary power and must be exercised for a proper purpose.

Under the common law there are decisions which took a line more favourable to management when exercising their powers for the overarching

company or cause damage to the company's interests, they are entitled to use their powers to protect the company.

152

53 Ibid.

154 Hogg v Cramphorn Ltd supra 427.

155 Hogg v Cramphorn Ltd supra 428.

156 Hogg v Cramphorn Ltd supra 427.

157 lbid.

158 In Howard Smith Ltd v Ampol Petroleum Ltd supra 1135-1136 Lord Wilberforce submitted that "though the reported decisions, naturally enough, are expressed in terms of their own facts, there are clear considerations of principle which support the trend they establish. The constitution of a limited company normally provides for directors, with powers of management, and shareholders, with defined voting powers, having power to appoint the directors, and to take, in general meeting, by majority vote, decisions on matters not reserved for management. Just as it is established that directors, within their management powers, may take decisions against the wishes of the majority of shareholders, and indeed that the majority of shareholders cannot control them in the exercise of these powers while they remain in office (Automatic Self-Cleansing Filter Syndicate Co Ltd v Cuninghame [1906] 2 Ch. 34), so it must be unconstitutional for directors to use their fiduciary powers over the shares in the company purely for the purpose of destroying an existing majority, or creating a new majority which had not previously exististed. To do so is to interfere with that element of the company's constitution which is separate from and set against their powers. If there is added, moreover, to this immediate purpose, an ulterior purpose to enable an offer for shares to proceed which the existing majority was in a position to block, the departure from the legitimate use of the fiduciary power becomes not less, but all the greater. The right to dispose of shares at a given price is essentially an individual right to be exercised on individual decision and on which a majority, in the absence of oppression or similar impropriety, is entitled to prevail. Directors are of course entitled to offer advice, and bound to supply information, relevant to the making of such a decision, but to use their fiduciary power solely for the purpose of shifting the power to decide to whom and at what price shares are to be sold, cannot be related to any purpose for which the power over the share capital was conferred upon them". There are, however, limits to the constitutional principle. See Cayne v Global Natural Resources plc unreported decision (August 12, 1982 , Ch. Div.) cited in DeMott "Comparative Dimensions of Takeover Regulation" 198765 Wash ULQ 69, 75-76; and see also Bennett "The Ascertainment of Purpose when Bona Fides are in Issue - Some Logical Problems" 198912 Sydney LR 5. An appeal from Meggary V-C is affirmed on other grounds and reported in [1984] 1 All ER 225; See also Heron International Ltd $v$ Lord Grade [1983] BCLC 244; and Advance Bank of Australia Ltd v FAl Insurance Australia Ltd (1987) 12 ACLR 118 CA (NSW). 
promotional purpose of the best interests of the company. ${ }^{159}$ In Harlowe's Nominees Pty Ltd $v$ Woodside (Lakes Entrance) Oil Co NL ${ }^{160}$ an issue of shares was made to an oil company in order to secure the financial stability of the company. This had the effect of frustrating the plaintiff's takeover bid. ${ }^{161}$ The issue of shares was upheld because its purpose had not been to defeat the plaintiff's endeavour to obtain control or preserve the directors' positions on the board of the company. ${ }^{162}$

The court held that, although the power to issue shares is provided primarily to increase the capital of the company, there may be occasions when the directors may fairly and properly issue shares for other reasons, provided those reasons relate to a purpose that will benefit the company as a whole, as distinguished from a purpose, for example, of maintaining control of the company in the hands of the directors themselves or their friends. ${ }^{163}$ The court held further that directors who are vested with the right and the duty of deciding what would be in the best interest of the company and how they are to be served, may be concerned with a wide range of practical considerations, and their judgment, if exercised in good faith and not for irrelevant purposes, is not open to review in the courts.

In Howard Smith Ltd $v$ Ampol Petroleum Ltd ${ }^{165}$ the Privy Council took a middle course approach. ${ }^{166}$ Two purposes appear to have existed. ${ }^{167}$ There was a desire to raise further finance for the company as well as the desire to defeat the takeover bid. ${ }^{168}$ The Court concluded that the primary or substantial purpose was to defeat a hostile takeover bid and held that the power was exercised improperly. ${ }^{169}$ The Court held that directors, within their management powers, may take decisions against the wishes of the majority of shareholders, and the majority of shareholders cannot control them in the exercise of these powers while they remain in office. ${ }^{170}$ However, it is unacceptable for directors to use their fiduciary powers over the shares in

159 Farrar "Business Judgment and Defensive Tactics in Hostile Takeover Bids" 198915 Canadian Business LJ 1528.

160 Supra.

161 Harlowe's Nominees Pty Ltd v Woodside (Lakes Entrance) Oil Co NL supra par 1-3.

162 lbid.

163 Harlowe's Nominees Pty Ltd v Woodside (Lakes Entrance) Oil Co NL supra par 6.

164 Ibid.

165 Supra 1126. This case concerned a takeover bid to take complete control of the company. Miller was in favour of a higher takeover bid by Howard Smith which they preferred to a lower takeover bid by a majority shareholder, Ampol, and an associate company. The Miller board wished to attract the higher bidder, so they issued shares to Howard Smith on the basis that Howard Smith would offer more for the company than Ampol. The effect of the share issue diluted Miller's share capital which turned Ampol's majority shareholding in Miller into a minority interest, thus reconstructing the majority shareholding and thereby it made the bid made by Howard Smith the more likely one to succeed. Ampol challenged the decision on the basis that the share issue was exercised for an improper purpose.

166 Farrar 1989 Canadian Business LJ 28.

167 Howard Smith Ltd v Ampol Petroleum Ltd supra 1134-1136.

168 Ibid.

169 Ibid.

170 Howard Smith Ltd v Ampol Petroleum Ltd supra 1135-1136. 
the company purely for the purpose of destroying an existing majority, or creating a new majority which did not previously exist. ${ }^{17}$

In Whitehouse $v$ Carlton Hotels Pty Ltd ${ }^{172}$ the Court took a narrow approach which may have refined the Howard Smith case. ${ }^{173}$ Whitehouse, the governing director, allotted shares to his sons to prevent his wife and daughters, also shareholders, from gaining control of the company upon his death. This desire was motivated by his belief that he was acting in the best interests of the company. ${ }^{174}$

The Court held that it is of no relevance that Whitehouse believed that it was in the overall interests of the company that the voting power attaching to the shares held by his former wife should be diluted to ensure that the control of the company in the period after his death would be in the hands of those whom he favoured. ${ }^{175}$ That belief was the reason for the allotment for the impermissible purpose. ${ }^{176}$ It did not constitute a competing, permissible purpose. ${ }^{177}$ The court held that, as a matter of logic and principle the preferable view was, regardless of whether the permissible purpose was the dominant one, or but one of a number of significantly contributing causes, the allotment would be invalidated if the impermissible purpose was causative in the sense that, but for its presence, the power would not have been exercised. ${ }^{17}$

In Minister of Water Affairs and Forestry $v$ Stilfontein Gold Mining Co $L t d^{179}$ all the directors of a listed public company resigned. ${ }^{180}$ The directors' justification for their resignation was that they had been advised by legal counsel of their potential exposure to liability for reckless trading because the company did not have the sufficient funds to comply with the directives of a court order. ${ }^{181}$ The court held that directors are under a duty to act in good faith in the interests of the company. ${ }^{182}$ The court concluded that the directors had not acted in good faith and upon reasonable grounds in resigning. ${ }^{183}$ Their resignations had precluded them from discharging their duties to the company and its members, and could not be said to be in the best interests of the company. ${ }^{184}$ By accepting appointment as directors of a listed company they had accepted the duties and obligations that go with it

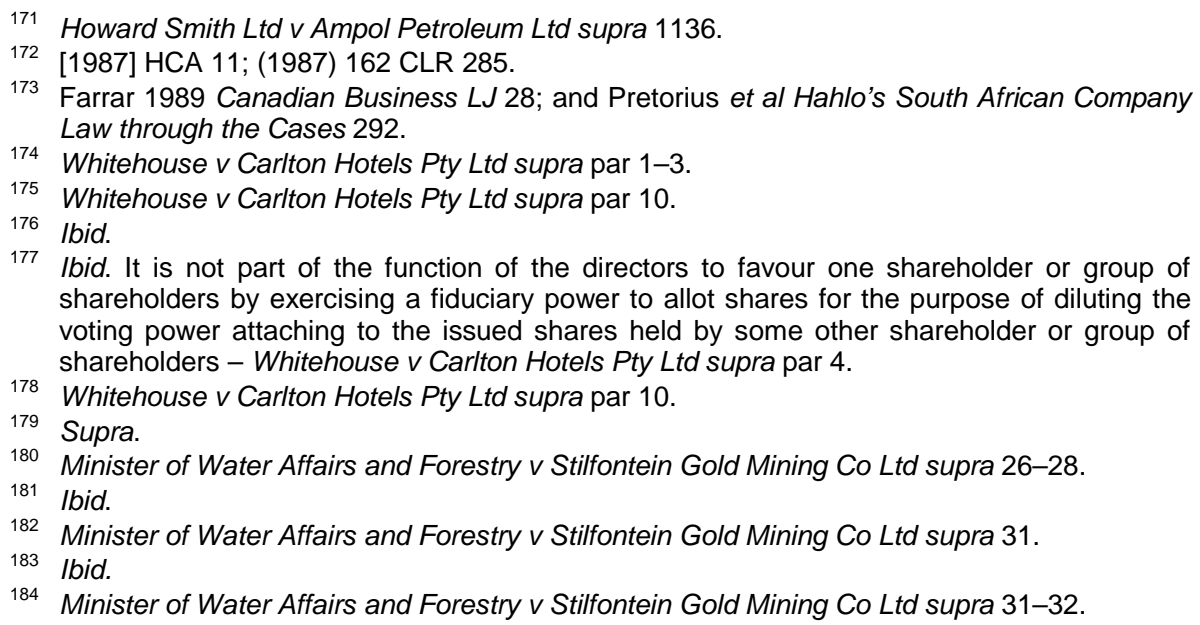

$177 \mathrm{Ibid}$. It is not part of the function of the directors to favour one shareholder or group of shareholders by exercising a fiduciary power to allot shares for the purpose of diluting the voting power attaching to the issued shares held by some other shareholder or group of shareholders - Whitehouse v Carlton Hotels Pty Ltd supra par 4.

178 Whitehouse $v$ Carlton Hotels Pty Ltd supra par 10.

179 Supra.

180 Minister of Water Affairs and Forestry v Stilfontein Gold Mining Co Ltd supra 26-28.

181 Ibid.

182 Minister of Water Affairs and Forestry v Stilfontein Gold Mining Co Ltd supra 31.

183 lbid.

184 Minister of Water Affairs and Forestry v Stilfontein Gold Mining Co Ltd supra 31-32. 
and could not be allowed to merely walk away because it was convenient to do so, and they had acted irresponsibly by merely abandoning the company without notification. ${ }^{185}$

Directors may also be in breach of the duty to act in the best interests of the company if they do not comply with a legal rule, be it in terms of the 2008 Act or any other "law". ${ }^{186}$

If a director succeeds in satisfying the requirements of this provision in acting honestly and reasonably he will not be held liable for errors of judgment and/or poor business judgments or decisions. ${ }^{187}$ Furthermore if the requirements of section 76(4)(a)(i)-(iii) are satisfied, the courts will not, with the benefit of hindsight, second-guess company directors' business decisions or review the merits of the decision according to the rationality standard. ${ }^{188}$ The test to determine whether a director acted in good faith and in the best interests of the company is subjective as to means (what is to be done in order to promote the interests of the company) but objective as to ends (the interests of the company). ${ }^{19}$

\section{CONCLUSION}

The directors' fiduciary duties are partially codified in the standards of directors' conduct provision. ${ }^{190}$ It is not the intention of the Act to replace the common-law duties of directors, to the extent that they are not in conflict with the standards of directors' conduct provision. ${ }^{191}$ The Act also authorises and encourages the development of the common law. ${ }^{192}$ This will effectively provide the courts with the ability to develop the duties further in a South African context. ${ }^{193}$ The relationship between the statutory provision and the common law must be clear. ${ }^{194}$ Courts must interpret the language of the Act

185 Ibid.

186 Bester NO v Wright; Bester NO v Mouton; Bester NO v Van Greunen [2011] 2 All SA 75 (WCC); and Delport et al Henochsberg on the Companies Act 71 of 2008296.

187 In Harlowe's Nominees Pty Ltd v Woodside (Lake's Entrance) Oil Co NL supra par 6, it was held that "[d]irectors in whom are vested the right and duty of deciding where the company's interests lie and how they are to be served may be concerned with a wide range of practical considerations, and their judgment, if exercised in good faith and not for irrelevant purposes, is not open to review in the courts"; In Howard Smith Ltd v Ampol Petroleum Ltd supra 1131 it was held that "[t]here is no appeal on the merits from management decisions to courts of law: nor will courts of law assume to act as a kind of supervisory board over

188 Ibid. decisions within the powers of management honestly arrived at".

189 Blackman et al Commentary on the Companies Act 8-62; and Williams in Joubert and Faris (eds) The Law of South Africa Vol 4(2) (First Reissue) par 124.

190 S 76 read with $\mathrm{7} 77(2)$.

191 Delport The New Companies Act Manual 90; Delport et al Henochsberg on the Companies Act 71 of 2008 288; Davis et al Companies and Other Business Structures in South Africa: Commercial Law 2ed 111; Cassim et al Contemporary Company Law 509; Cassim et al The Law of Business Structures 284-285; Stein and Everingham The New Companies Act Unlocked 244; and Williams "Companies" in Joubert and Faris (eds) The Law of South Africa Vol 4(1) par 238 fn 5.

192 See s 5(2), 76, 77(2) and 158(a).

193 See Amdocs SA Joint Enterprise (Pty) Ltd v Kwezi Technologies (Pty) Ltd supra par 8.

194 Esser Recognition of Various Stakeholder Interests in Company Management 298; and Delport et al Henochsberg on the Companies Act 71 of 2008289. 
to give effect to the purposes the Act intends to achieve. ${ }^{195}$ The Act also provides remedies to ensure that the promotion of these purposes may be achieved. ${ }^{196}$ When a matter is required to be determined in terms of the directors' standard of conduct provision a court must develop the common law as necessary to improve the realisation and enjoyment of rights established by the Act. ${ }^{197}$ It must promote the spirit, purpose and objects of the $\mathrm{Act}^{198}$ and if the directors' standard of conduct provision, read in its context, can be reasonably construed to have more than one meaning, the court must prefer the meaning that best promotes the spirit and purpose of the Act, and will best improve the realisation and enjoyment of rights.

Directors are required to exercise their powers and perform their functions in good faith and for a proper purpose, ${ }^{200}$ with the overarching promotional purpose being the best interests of the company. ${ }^{201}$ This is a fundamental duty which qualifies the exercising of any of the powers which the directors in fact have. ${ }^{202}$ The justifications for the deference aspect of the business judgment rule is multifaceted but begins with the fact that directors are conferred with a statutory authority to manage the business and affairs of the company on whose boards they serve. ${ }^{203}$ In turn, it is recognised that the exercising of this statutory power carries with it certain fundamental fiduciary obligations to the company. ${ }^{204}$ The business judgment rule ${ }^{205}$ provides the circumstances in which the duty to act in the best interests of the company and the duty of care, skill and diligence will be satisfied by a director. ${ }^{20}$

The "best interests of the company" is an indefinite phrase and possibly has different meanings in different contexts. ${ }^{207}$ It is clear that the precise wording of "company" in section 76(3)(b) and in section 77(2)(a) and (b) indicates that the duties are owed to the company. The problematic area is whose "interests" are meant with the word "company". ${ }^{208}$ The general rule is that "the interests of the company as a whole" are the interests of the shareholders qua shareholders, as a general body and the company as a separate legal entity. ${ }^{209}$ This approach relates to the shareholders

195 See s 5(1), s 6(1) and 7.

196 S 158.

197 S 158(a).

198 S 158(b)(i). See the DTI South African Company Law for the $21^{\text {st }}$ Century Guidelines for Corporate Law Reform 2004 and the DTI Notice of intention to introduce a Bill into Parliament, GG 29630, GNe 166 of 2007 dated 2007-02-12 for a background the on the spirit and objectives of the Act.

199 S 158(b)(ii).

$200 \mathrm{~S} 76(3)(\mathrm{a})$.

201 S 76(3)(b); and see also Visser Sitrus (Pty) Ltd v Goede Hoop Sitrus (Pty) Ltd supra par 80.

202 Minister of Water Affairs and Forestry v Stilfontein Gold Mining Co Ltd supra 31; Visser Sitrus (Pty) Ltd v Goede Hoop Sitrus (Pty) Ltd supra par 80; and see, for instance, s 38.

203 S 66(1)

$204 \mathrm{~S} 76$.

205 S 76(4)(a); and see Delport et al Henochsberg on the Companies Act 71 of 2008297.

206 S 76(4)(a); and see also Visser Sitrus (Pty) Ltd $v$ Goede Hoop Sitrus (Pty) supra par 80.

207 Blackman et al Commentary on the Companies Act 8-67; Sealy 1989 Monash University LR 269-270; and see also Mills v Mills supra 188-189.

208 S 1; and Cassim et al Contemporary Company Law 515 fn 39.

209 Blackman et al Commentary on the Companies Act 8-67; and Delport et al Henochsberg on the Companies Act 71 of 2008296. 
collectively, all the shareholders both present and future and the company as a separate legal entity. ${ }^{210}$ This indicates their interests in the prosperity of the company as a business concern. ${ }^{211}$ Considering that one of the purposes of the Act is to reaffirm the concept of the company as a means of achieving economic and social benefits ${ }^{212}$ the better view is that it can mean different things in different contexts. ${ }^{213}$ Irrespective of what the legal rules are, good management will attempt to balance the interests of shareholders, employees, creditors, consumers, the environment and society in general, having regard to the nature and size of the company and the interests most affected by any particular transaction or decision. ${ }^{214}$ This could, in appropriate circumstances, be extended to include the environment. ${ }^{215}$

Section 76(4) introduces the business judgment rule. If the directors' decision-making process is not tainted by a personal financial self-interest ${ }^{216}$ the business judgment rule provides a director with a shield from liability, provided certain requirements are satisfied. ${ }^{217}$ The business judgment rule relates to the decision-making aspect of the duty of care, skill and diligence but presumes that directors, in making a business decision, complied with their duty to become informed about the matter, and that the decision was made in the best interests of the company. ${ }^{218}$

The business judgment rule has two principle features. Firstly, that a court will presume that in making a business decision the directors of a company acted on an informed basis, in good faith and with a rational basis that an action, or inaction, was taken in the best interest of the company. ${ }^{219}$ Secondly, unless a plaintiff can rebut the presumptions created firstly, that is, unless it can be shown that a board of directors did not act on an informed basis, in good faith, and with a rational basis that an action, or inaction, was taken in the best interests of the company, the board of directors will not incur any liability as a result of its decision, and a court will not disturb the decision itself, so long as the decision can be attributed to any rational business purpose. 220

This indicates that the business judgment rule functions as a procedural rule as well as a substantive rule of law. On the procedural level, the business judgment rule creates a presumption of an informed business decision, in good faith and was made with a rational belief that the decision was taken in the best interests of the company. ${ }^{221}$ In other words, the rule presumes the directors have complied with their duty to become informed

210 Esser Recognition of Various Stakeholder Interests in Company Management 211.

211 Blackman et al Commentary on the Companies Act 8-69.

212 S 7(d)

213 Sealy 1989 Monash University LR270.

214 Pretorius et al Hahlo's South African Company Law Through the Cases 294.

215 In Company Secretary of Arcelormittal South Africa v Vaal Environmental Justice Alliance supra 288

216 See $\mathrm{s} 76(4)$ (ii) in this regard.

217 S 76(4)(a)

218 S 76(4)(a)(i) and (iii).

219 S 76(4)(a)

$220 \mathrm{~S} 76(4)(\mathrm{a})(\mathrm{i})$ and (iii).

221 S 76(4)(a)(iii). 
about the matter and that the decision was made in the best interests of the company. ${ }^{222}$ The procedural aspect thus requires the plaintiff to establish facts to prove the elements of a breach of duty. ${ }^{223}$ At this point the substantive aspect of the rule requires the court to defer to a business judgment made by the directors, provided their decision is not completely irrational. ${ }^{224}$ This aspect prevents judicial review of the merits of the decision and protects the decision from being challenged. The criterion employed to determine rationality is an objective one. ${ }^{225}$ The threshold is different from, and easier satisfied than, a determination as to whether the decision was objectively in the best interests of the company. ${ }^{226}$

Thus, in the absence of any reasonable ground for deciding that a certain course of action is for the benefit of the company, may be a ground for finding lack of good faith. ${ }^{227}$ If the decision is found to be objectively irrational section 76(4) will not provide protection. This indicates the ever present undercurrent of the aspect of good faith in making business decisions that affect the best interests of the company. ${ }^{228}$ Even if a director believes that he is acting in the best interests of the company he will act in breach of this duty if there are no grounds on which reasonable men could come to the same decision. 229 This allows the court to objectively assess the directors' intentions with its own assessment of the best interests of the company at the relevant time. ${ }^{230}$ Whether the company suffers a loss or in actual fact benefits, is irrelevant. ${ }^{231}$ Directors must exercise discretion. ${ }^{232}$ If directors even fail to consider the interests of their company the objective test applies. ${ }^{233}$ A director who in good faith, but mistakenly, believes that the interests he wishes to promote are the interests of the company, will, despite his good faith belief, act in breach of this duty. ${ }^{234} \mathrm{~A}$ director must act in a way which he conceives to be for the benefit of the company as a whole, as that concept is understood by the law. ${ }^{235}$ Accordingly the test as to means is

222 Visser Sitrus (Pty) Ltd v Goede Hoop Sitrus (Pty) Ltd supra par 73.

${ }^{223}$ Visser Sitrus (Pty) Ltd v Goede Hoop Sitrus (Pty) Ltd supra.

224 Visser Sitrus (Pty) Ltd v Goede Hoop Sitrus (Pty) Ltd supra par 73; see also Veasey "The Defining Tension in Corporate Governance in America" 199752 The Business Lawyer 393 394 noting that under the business judgment rule, it is difficult to demonstrate that a decision was irrational; and see also Rosenberg "Galactic Stupidity and the Business Judgment Rule" 200632 Journal of Corporation Law 301 321-322, arguing that review for (

226 Ibid.

227 Shuttleworth v Cox Brothers \& Co (Maidenhead) Ltd supra 23.

228 Cassim et al Contemporary Company Law 564.

229

Blackman et al Commentary on the Companies Act 8-64-2; Naude "Loans or Securities by Subsidiaries: The New Section 37 and Abuse of Control" 1979 MBL 8 17; and Parsons "Directors' Duty of Good Faith" 19675 MULR 395 416-417. See, eg, Neptune (Vehicle Washing Equipment) Ltd v Fitzgerald (No 2) [1995] 1 BCLC 352 (ChD); and see further Re W \& M Roith Ltd [1967] 1 All ER 427.

230 Howard Smith Ltd $v$ Ampol Petroleum Ltd supra 1131-1132.

231 Blackman et al Commentary on the Companies Act 8-66.

232 Ibid.

233 Re Halt Garage Ltd [1982] 3 All ER 10161032.

${ }^{234}$ Blackman et al Commentary on the Companies Act 8-67.

235 lbid. 
subjective ${ }^{236}$ as long as the directors have correctly identified the interests of the company as they are defined in law, ${ }^{237}$ but the test as to ends, the best interests of the company, the end design for which directors must exercise their powers, is objective.

Based on the common law and case law the research identified the following categories of conduct as conduct that may not constitute good faith, thereby indicating that the rationality criterion will not be satisfied: (i) conduct motivated by a purpose other than the best interests of the company; ${ }^{239}$ (ii) conduct motivated by subjective bad faith; $; 40$ (iii) conduct that involves an intentional violation of law; ${ }^{241}$ and (iv) intentional dereliction of duty. ${ }^{242}$

\footnotetext{
236 The Smith and Fawcett rule that directors must exercise their powers bona fide in what they consider and not what a court may consider to be in the interests of the company.

237 Blackman et al Commentary on the Companies Act 8-67.

238 Blackman et al Commentary on the Companies Act 8-64-2.

239 See Hogg v Cramphorn Ltd supra; Howard Smith Ltd v Ampol Petroleum Ltd supra; and Whitehouse $v$ Carlton Hotels Pty Ltd.

240 See Charterbridge Corporation Ltd v Lloyds Bank Ltd supra; and Shuttleworth $v$ Cox Brothers \& Co (Maidenhead) Ltd supra.

241 See Bester NO v Wright, Bester NO v Mouton; and Bester NO v Van Greunen supra.

242 See Minister of Water Affairs and Forestry v Stilfontein Gold Mining Co Ltd 2006 (5) SA 333 (W).
} 